\title{
NOTE
}

\section{Spatial distribution and an absolute density estimate of juvenile spot Leiostomus xanthurus in the tidal fringe bordering a North Carolina salt marsh}

\author{
Kevin D. E. Stokesbury*, Steve W. Ross \\ North Carolina National Estuarine Research Reserve, Center for Marine Science Research, University of North Carolina at Wilmington, \\ 7205 Wrightsville Avenue, Wilmington, North Carolina 28403, USA
}

\begin{abstract}
We used a nested quadrat design to precisely and accurately estimate the absolute density and spatial distribution of juvenile spot Leiostomus xanthurus in the tidal fringe of a salt marsh. Fifty white quadrats 10 of each size: 32 , $64,128,256$, and $512 \mathrm{~cm}^{2}$ ) were randomly placed within two $10 \mathrm{~m}^{2}$ plots adjacent to a pier. The number of fish over each quadrat was counted on 7 dates between 17 March and 7 April 1995. Quadrats did not attract or repel fish and the observer's experimental bias was low. L. xanthurus had a contagious distribution, with aggregations covering approximately $128 \mathrm{~cm}^{2}$ L. xanthurus densities ranged from 18.33 to $28.30 \mathrm{fish} \mathrm{m}^{-2}$ ( 3.0 to $5.9 \%$ level of precision), while densities estimated from shore seines ranged from 0.50 to $4.96 \mathrm{fish} \mathrm{\textrm {m } ^ { - 2 }}$ (97.2 to $200.0 \%$ level of precision). Correction factors should be estimated before fish density estimates derived from net samples are used in ecosystem modeling, carrying capacity estimates or vital statistics for this habitat.
\end{abstract}

KEY WORDS: Leiostomus xanthurus - Precision - Accuracy . Relative density - Absolute density - Spatial distribution. Quadrat - Shore seine

The salt marsh is an important nursery for many fish as prey are abundant and the spatially complex shallow water habitat offers protection from predation (Boesch \& Turner 1984, Currin et al. 1984, Peterson \& Turner 1994, Miltner et al. 1995). Spot Leiostomus xanthurus, a successful estuarine Sciaenid, supports a large commercial and recreational fishery (Miller \& Dunn 1980, Warlen \& Burke 1990). These fish spawn offshore in the winter and their larvae move into the estuaries where they remain until the fall when they migrate back to the ocean (Currin et al. 1984). Each marsh system supports a seasonally residential population of these fish and emigration rates of individuals are low (Weinstein et al. 1984).

\footnotetext{
- Present address: University of Alaska Fairbanks, Institute of Marine Science, School of Fisheries and Ocean Sciences, Fairbanks, Alaska 99775-7220, USA.

E-mail: kstokes@ims.alaska.edu
}

Few studies estimate the absolute density of age 0 to 1 fishes in estuarine nursery habitats. Most studies examining fishes in salt marshes use either active or passive nets, including trawls (Ross \& Epperly 1985 , Rulifson 1991. Miltner et al. 1995), plankton nets, dip nets and traps (Talbot \& Able 1984), and flume nets and seines (Peterson \& Turner 1994). These gears provide relative estimates of density based on the catch per unit effort (CPUE). The net's selectivity, precision and efficiency must be estimated to provide an absolute estimate of density, the number of individuals per unit area (Gunderson 1993). Absolute densities are required to calculate statistics, such as reproductive rate, energy flow and nutrient cycles, vital to population dynamic estimates and ecosystem models (Ricker 1975, Begon \& Mortimer 1982, Krebs 1989, Putman 1994). Tag-recapture techniques provide absolute density estimates but are difficult to implement as juvenile fish are delicate and tagging mortality is usually high (i.e. $38.4 \%$, Weinstein 1983, Weinstein et al. $1984 ; 53$ to $95 \%$, Weinstein \& O'Neil 1986)

We estimated the absolute density and the small scale spatial distribution of juvenile spot Leiostomus xanthurus in the tidal fringe along a salt marsh. We periodically counted individuals as they moved over quadrats of various sizes. We examined the accuracy of this technique compared with traditional shore seining in the same habitat.

Materials and methods. Two plots of $10 \mathrm{~m}^{2}(2 \times 5 \mathrm{~m})$ were established $3 \mathrm{~m}$ below a Spartina alterniflora marsh (area $=30700 \mathrm{~m}^{2}$ ), each plot approximately $1 \mathrm{~m}$ away from either side of a pier (on piles, $2 \mathrm{~m}$ above the substratum) in Masonboro Sound, North Carolina, USA $\left(34^{\circ} 08.387^{\prime} \mathrm{N}, 77^{\circ} 51.784^{\prime} \mathrm{W}\right)$, on 16 March 1995 (Fig. 1). The substratum of fine sand was homogeneous, except for a few small patches of oysters, and the intertidal gradient was smooth along the coast. Graduated markers were placed at the seaward and 


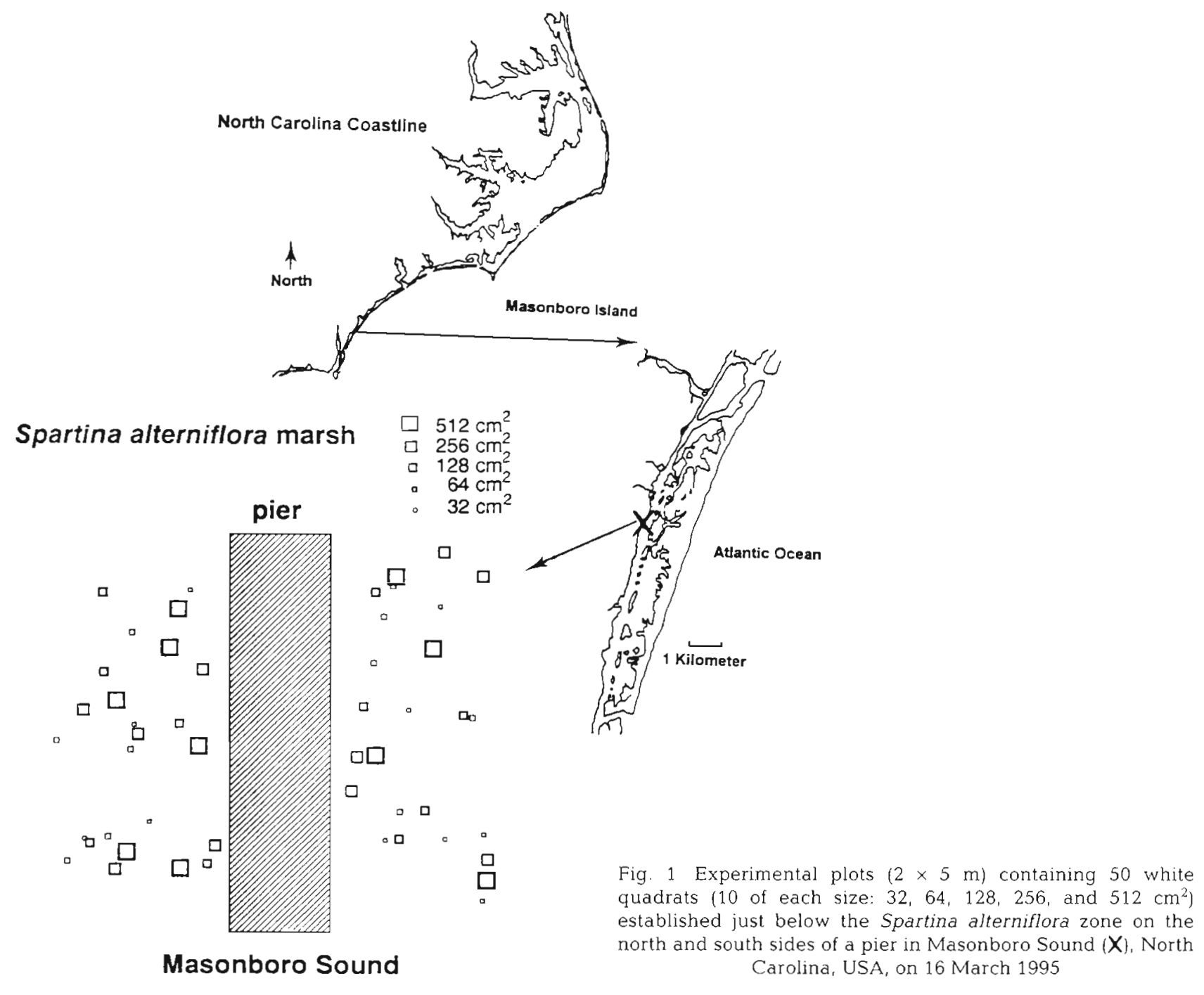

shore ends of each plot to measure water depth. Fifty quadrats were divided into 5 size groups, covering areas of $32,64,128,256$, and $512 \mathrm{~cm}^{2}$, and 25 randomly selected quadrats were randomly placed within each plot (Fig 1). Quadrats were made of press board with a white plastic waterproof coating on one side and anchored to the substratum with a spike.

Observations of fish density were made at mid-tide on 7 days with calm water conditions and good water clarity between 17 March and 7 April 1995. Water quality was similar during the 7 observations: at a depth of $0.7 \mathrm{~m}$ mean water temperature was $15.3^{\circ} \mathrm{C}$ $(\mathrm{SD}=0.85)$, mean salinity was $32.7 \%(\mathrm{SD}=3.40)$ and mean dissolved oxygen was $7.6 \mathrm{mg} \mathrm{l}^{-1}(\mathrm{SD}=0.64)$. Neither experimental plot was shaded by the pier during observations. Approximately $15 \mathrm{~min}$ before an observation the quadrats were cleared of sand and replaced in their original positions if they had been disturbed by waves. The observer, situated on the pier, counted the number of fish over each quadrat, spending approximately $5 \mathrm{~s}$ per quadrat, and completed counts in each plot within 2 to $3 \mathrm{~min}$. Observations were made in water depths ranging from 5 to $50 \mathrm{~cm}$ over the experimental plots. Observations were separated by at least 10 min, however, if a boat wake reduced water clarity, the following observation was delayed until the clarity returned to the pre-wake condition.

Two control experiments estimated experimental bias. To determine if fish were attracted to or repelled by the white surface of the quadrats, areas of 128,256 , and $512 \mathrm{~cm}^{2}$ were marked, using small nails as corner markers, near quadrats of the same size. The number of fish over the white quadrats and the sand control areas were counted at the same time. This control was only performed when water clarity and light conditions allowed an unobstructed view of the bottom and water column, ensuring that all the fish in the area could be counted. To estimate the observer's ability to accu- 
rately count the number of fish over each quadrat from the pier, an unknown number of Leiostomus xanthurus were placed randomly in 4 white buckets (bottom area of $143 \mathrm{~cm}^{2}$ ) containing about $10 \mathrm{~cm}$ of water. The number of fish in each bucket was counted from the pier using a $5 \mathrm{~s}$ time interval per bucket. Then the contents of each bucket was poured into a net and the actual number of fish were counted. In all, 36 control counts were completed

The frequency distributions of fish counts for each quadrat size were compared with a Poisson distribution (random) and a negative binomial distribution (contagious) using chi-squared analysis, and Cochran's rule, to determine spatial patterns (Elliott 1971 , Sokal \& Rohlf 1981). Further, the Morisita's Index of Dispersion was calculated for each quadrat size to determine spatial patterns and aggregation size. Although Morisita's Index is affected by the number of quadrats, this bias should be low as the number of counts for each quadrat size was high and similar (ranging from 216 to 261 ). The size of a fish aggregation, represented as the area of substratum the aggregation covers, was estimated by dividing the Morisita's Index for one quadrat size by the Morisita's lndex for the next larger quadrat size and then plotting this ratio over the larger quadrat size (Elliott 1971). A peak occurs when the quadrat size and aggregation size are approximately equal. The Morisita's Standardized Index was also calculated for each size of quadrat and may be the best index of dispersion as it is independent of population density and sample size (Krebs 1989). Density estimates (fish $\mathrm{m}^{-2}$ ) and levels of precision were derived from the means and standard deviations of fish counts over each quadrat size.

On 3 dates shore seines were used to estimate the abundance, species composition, and length frequencies of fish present in the tidal fringe. A single collection on 21 March and 3 collections on 10 April were made using a $15.2 \mathrm{~m}, 3.2 \mathrm{~mm}$ mesh minnow seine, swiping an area of $50 \mathrm{~m}^{2}$ along the shore. On 2 April, 4 collections were made using a $2.6 \mathrm{~m}, 20 \mathrm{~mm}$ mesh minnow seine, sweeping 1 of 2 measured distances (125 or $187 \mathrm{~m}^{2}$ ). Fish species collected in these seines were identified, counted, and the fork lengths ( $\mathrm{mm}$ ) of the 3 dominant species were measured. Density estimates (fish $\mathrm{m}^{-2}$ ) and levels of precision were derived from the means and standard deviations calculated from the seine collections. The relative density estimates of Leiostomus xanthurus calculated from these shore seines were compared with the absolute density estimates calculated from the quadrat observations.

Results. Leiostomus xanthurus was the most abundant fish in the tidal fringe, representing 94.4 and $97.4 \%$ of the seine collections on 21 March and 2 April respectively, and $27.1 \%$ on 10 April 1995 (Table 1). L xanthurus was smaller than the Fundulus spp. (Table 1). It was possible to distinguish $L$. xanthurus from Fundulus spp. and other species in the shallow water because of their differences in size, morphology and swimming patterns. Further, they appeared to be spatially segregated, the Fundulus spp. preferred the extreme edge of the tidal fringe $(<5 \mathrm{~cm}$ water depth) while L. xanthurus preferred $>5 \mathrm{~cm}$ water depth Therefore, the majority of fish observed over the quadrats were probably L. xanthurus.

Daily observations of fish were similar (KruskalWallis test, $\mathrm{df}=6, H=12.5, \mathrm{p}>0.05$ ) throughout the experiment, except for the $256 \mathrm{~cm}^{2}$ quadrats $(\mathrm{H}=13.0$, $p=0.04$ ) (Table 2). The significant difference between daily fish counts for the $256 \mathrm{~cm}^{2}$ quadrats was probably due to the single large mean of $1.29(\mathrm{SD}=2.44)$ on 23 March.

The experimental plates did not seem to attract or repel fish. Although the mean counts of fish were generally higher over plates compared with sand substratum, the counts were not significantly different (Table 3). Fish did not appear to vary their direction or speed when approaching a plate.

The experimental bias of the observer counting the number of fish over a quadrat was low. There was a $90.3 \%$ similarity between the observed counts and actual number of fish in the buckets. The observed mean of 3.19 fish per bucket $(\mathrm{SD}=2.85$ ) was slightly less, but not significantly different, than the actual mean of 3.36 fish per bucket $(S D=3.02$ ) (Wilcoxon matched pairs test, $n=36, p=0.37$ )

Table 1 Frequency of species, mean (mm) lengths and standard deviations (SD) for fish collected with shore seines in the tidal fringe near the experimental plots in Masonboro Sound (NC, USA)

\begin{tabular}{|c|c|c|c|c|c|c|c|c|c|c|}
\hline & \multicolumn{4}{|c|}{-21 March -} & \multicolumn{2}{|c|}{-2 April - } & \multicolumn{4}{|c|}{$\longrightarrow 10$ April } \\
\hline & Count & $\%$ & Length & SD & Count & $\%$ & Count & $\%$ & Length & $\mathrm{SD}$ \\
\hline Leiostomus xanthurus & 1240 & 94.4 & 25.9 & 2.87 & 1922 & 97.4 & 52 & 27.1 & 32.2 & 4.00 \\
\hline Fundulus majalis & 43 & 3.3 & 47.2 & 17.20 & 0 & 0.0 & 37 & 19.3 & 47.6 & 10.02 \\
\hline Fundulus heteroclitus & 24 & 1.8 & 43.0 & 13.40 & 2 & 0.1 & 102 & 53.1 & 34.7 & 8.12 \\
\hline Other & 7 & 0.5 & & & 49 & 2.5 & 1 & 0.5 & & \\
\hline Total & 1314 & & & & 1973 & & 192 & & & \\
\hline
\end{tabular}


Table 2. Leiostomus xanthurus. Means, standard deviations (SD), maximum number, Morisita's Index and standardized Morisita's Index of Dispersion of fishes counted over the 5 quadrat sizes

\begin{tabular}{|c|c|c|c|c|c|c|c|c|c|c|c|c|}
\hline \multirow{3}{*}{ Date } & \multirow{3}{*}{ Time } & \multirow{3}{*}{ Tide } & & & \multirow{2}{*}{\multicolumn{2}{|c|}{$64 \mathrm{~cm}^{2}$}} & \multirow{2}{*}{\multicolumn{2}{|c|}{$\begin{array}{r}\text { - Quadrat } \\
128 \mathrm{~cm}^{2}\end{array}$}} & \multirow{2}{*}{\multicolumn{2}{|c|}{$256 \mathrm{~cm}^{2}$}} & \multirow{2}{*}{\multicolumn{2}{|c|}{$512 \mathrm{~cm}^{2}$}} \\
\hline & & & \multicolumn{2}{|c|}{$32 \mathrm{~cm}^{2}$} & & & & & & & & \\
\hline & & & Mean & SD & Mean & $\mathrm{SD}$ & Mean & $\mathrm{SD}$ & Mean & SD & \multicolumn{2}{|c|}{ Mean SD } \\
\hline $17 \mathrm{Mar}$ & $11: 50$ & ebb & 0.00 & & 0.31 & 0.70 & 0.28 & 0.67 & 0.79 & 1.31 & 1.63 & 2.75 \\
\hline $20 \mathrm{Mar}$ & $13: 55$ & ebb & 0.00 & & 0.04 & 0.30 & 0.04 & 0.21 & 0.31 & 0.90 & 0.37 & 1.24 \\
\hline $22 \mathrm{Mar}$ & $08: 05$ & flood & 0.14 & 0.49 & 0.31 & 0.89 & 0.75 & 0.27 & 0.75 & 1.34 & 1.60 & 2.79 \\
\hline $23 \mathrm{Mar}$ & $09: 35$ & flood & 0.16 & 0.42 & 0.20 & 0.46 & 0.44 & 0.94 & 1.29 & 2.44 & 1.29 & 2.58 \\
\hline $29 \mathrm{Mar}$ & $15: 15$ & flood & 0.00 & & 0.20 & 0.56 & 0.15 & 0.37 & 0.35 & 0.71 & 0.27 & 0.60 \\
\hline 4 Apr & $08: 26$ & flood & 0.09 & 0.29 & 0.20 & 0.47 & 0.58 & 1.22 & 0.68 & 1.25 & 0.66 & 1.49 \\
\hline $7 \mathrm{Apr}$ & $09: 26$ & flood & 0.02 & 0.15 & 0.08 & 0.28 & 0.21 & 0.41 & 0.26 & 0.58 & 0.90 & 2.38 \\
\hline \multicolumn{3}{|c|}{ Overall mean } & 0.07 & 0.30 & 0.18 & 0.55 & 0.36 & 0.87 & 0.62 & 1.38 & 0.94 & 2.16 \\
\hline \multicolumn{3}{|c|}{ Sample size (n) } & 250 & & 216 & & 247 & & 236 & & 261 & \\
\hline \multicolumn{3}{|c|}{ Number of fish counted } & 18 & & 39 & & 89 & & 147 & & 245 & \\
\hline \multicolumn{3}{|c|}{ Maxımum fish per quadrat } & 2 & & 4 & & 5 & & 13 & & 15 & \\
\hline \multicolumn{3}{|c|}{ Morisita's Index of Dispersion } & 4.90 & & 4.66 & & 4.10 & & 4.29 & & 5.21 & \\
\hline \multicolumn{3}{|c|}{ Standardized Morisita's Index } & 0.50 & & 0.51 & & 0.51 & & 0.51 & & 0.51 & \\
\hline
\end{tabular}

Table 3. Leiostomus xanthurus. Means and standard deviations (SD) of fish over sand and white quadrats. The $t$-test indicated no significant difference between means of each quadrat size at $\mathrm{p}=0.05$

\begin{tabular}{|c|c|c|c|c|c|c|}
\hline & 128 & $\mathrm{~cm}^{2}$ & 256 & $\mathrm{~cm}^{2}$ & \multicolumn{2}{|c|}{$512 \mathrm{~cm}^{2}$} \\
\hline & Sand & White & Sand & White & Sand & White \\
\hline Mean & 0.77 & 0.92 & 1.64 & 2.00 & 2.14 & 2.93 \\
\hline $\mathrm{SD}$ & 1.01 & 1.12 & 1.65 & 1.36 & 1.96 & 2.43 \\
\hline Count & 10 & 12 & 23 & 28 & 30 & 41 \\
\hline$n$ & 13 & 13 & 14 & 14 & 14 & 14 \\
\hline $\mathrm{df}$ & 24 & & 26 & & 26 & \\
\hline$t$ & -0.37 & & -0.63 & & -0.94 & \\
\hline $\mathrm{p}$ & 0.72 & & 0.54 & & 0.44 & \\
\hline
\end{tabular}

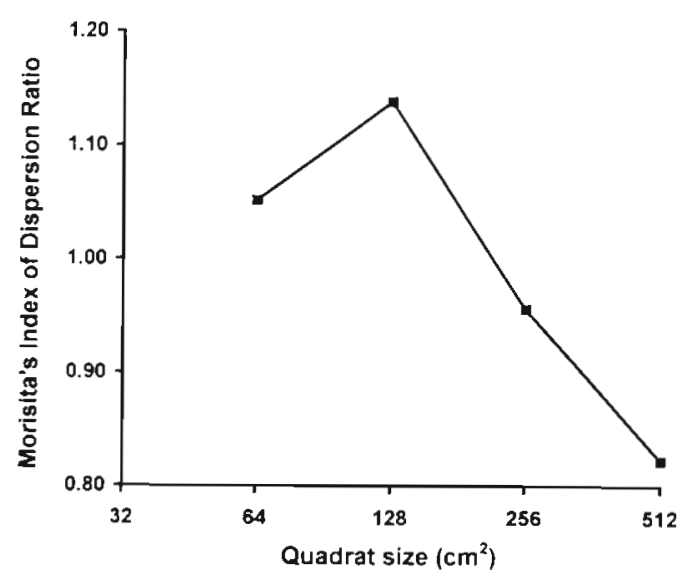

Fig. 2. Leiostomus xanthurus. Aggregation (school) size of juvenile spot in the salt marsh tidal fringe. Peaks in the line occur when quadrat size and aggregation size are approximately equal
Observed distributions of Leiostomus xanthurus over the 2 smaller-sized quadrats agreed with the Poisson distribution, indicating a random distribution $(\mathrm{p}>0.05$ : $\left.32 \mathrm{~cm}^{2}, \mathrm{df}=1, \chi^{2}=0.52 ; 64 \mathrm{~cm}^{2}, \mathrm{df}=1, \chi^{2}=2.67\right)$. Observed distributions of $L$. xanthurus over the 3 larger quadrats agreed with the negative binomial distribution, indicating a contagious distribution $(\mathrm{p}>0.05$ : $128 \mathrm{~cm}^{2}, \mathrm{df}=2, \chi^{2}=4.27 ; 256 \mathrm{~cm}^{2}, \mathrm{df}=3, \chi^{2}=3.87$; $512 \mathrm{~cm}^{2}, \mathrm{df}=5, \chi^{2}=4.78$ ). The Morisita's Index of Dispersion and the Standardized Morisita's Index indicated that all of these distributions were contagious or nearly so (a value of $>0.5$ indicates a contagious distribution for the Standardized Morisita's Index of Dispersion) (Table 2). Aggregations of juvenile L. xanthurus covered an area of approximately $128 \mathrm{~cm}^{2}$ (Fig. 2).

The quadrat estimates ranged from 18.33 to 28.30 Leiostomus xanthurus $\mathrm{m}^{-2}$ and the estimates from the shore seines ranged from 0.50 to $4.96 \mathrm{~L}$. xanthurus $\mathrm{m}^{-2}$ (Table 4). The relative level of precision for the quadrat fish counts ranged from 3.0 to $5.9 \%$. The shore seines were less precise and required much larger sampling effort to reach the precision of the quadrat counts (Table 4).

Discussion. Leiostomus xanthurus density estimates were accurate, precise and similar between quadrats. $L$. xanthurus entered the study plots in small schools, covering approximately $128 \mathrm{~cm}^{2}$, moving parallel to the shore. The fishes dispersed while searching for food but the school did not completely disintegrate, and after 10 to $30 \mathrm{~s}$ the school reformed and continued along the shore.

Absolute density estimates require a defined sample area and an organism that is relatively immobile during the counting period (Krebs 1989, Gunderson 1993). 
Table 4. Leiostomus xanthurus. Comparison of standardized $\left(\mathrm{m}^{2}\right)$ absolute mean densities and $95 \%$ confidence limits (CL) from quadrat counts with standardized $\left(\mathrm{m}^{2}\right)$ relative mean densities and $95 \% \mathrm{CL}$ from shore seine collections

\begin{tabular}{|lcccccc|}
\hline & $\mathrm{n}$ & $\begin{array}{c}\text { Mean } \\
\left(\mathrm{m}^{-2}\right)\end{array}$ & $\begin{array}{c}95 \% \mathrm{CL} \\
\text { Lower }\end{array}$ & $\begin{array}{c}\text { Relative } \\
\text { precision (\%) }\end{array}$ & $\begin{array}{c}\text { 5\% relative } \\
\text { precision, } \mathrm{n}=\end{array}$ \\
\hline Quadrat & & & & & & \\
$32 \mathrm{~cm}^{2}$ & 250 & 22.50 & 10.80 & 34.20 & 3.02 & \\
$64 \mathrm{~cm}^{2}$ & 216 & 28.30 & 16.94 & 39.66 & 4.52 & \\
$128 \mathrm{~cm}^{2}$ & 247 & 28.20 & 19.71 & 36.69 & 5.26 & \\
$256 \mathrm{~cm}^{2}$ & 236 & 24.33 & 17.47 & 31.19 & 5.89 & \\
$512 \mathrm{~cm}^{2}$ & 261 & 18.33 & 13.06 & 23.60 & 5.39 & \\
Seine & & & & & & 757 \\
$21 \mathrm{Mar}$ & 1 & 4.96 & & & & 3200 \\
$2 \mathrm{Apr}$ & 2 & 2.93 & 0 & 5.73 & 97.27 & \\
$2 \mathrm{Apr}$ & 2 & 3.18 & 0 & 7.34 & 133.45 & \\
$10 \mathrm{Apr}$ & 3 & 0.50 & 0 & 1.48 & 200.00 & \\
\end{tabular}

Our small quadrat sizes and short counting time fulfilled these requirements. Both control experiments indicate a high degree of accuracy as quadrats did not seem to attract or repel fish and there was little observer experimental bias. Our visual density estimates are more than an order of magnitude higher than previous absolute density estimates in salt marshes, which ranged from 0.01 to 10.57 Leiostomus xanthurus $\mathrm{m}^{-2}$ using fyke nets or tag-recapture nets (Weinstein 1979, Weinstein \& O'Neil 1986, Varnell et al. 1995). These latter values agree with our shore seine density estimates.

Shore seine collections underestimated Leiostomus xanthurus density and were not precise. Nets are difficult to use in the salt marsh habitat, net selectivity is usually high and net efficiency is low (i.e. $32.3 \%$, Kjelson \& Johnson 1978, Boesch \& Turner 1984). Therefore, few studies are able to estimate absolute abundance of fish and instead use catch per unit effort (Talbot \& Able 1984, Pietrafesa et al. 1986, Peterson \& Turner 1994), a previously estimated absolute density (Currin et al. 1984 used Weinstein 1979), or convert data to individuals per unit area but disregard gear efficiency, accepting it as experimental bias (Vose \& Bell 1994). Using quadrats to estimate absolute fish density is advantageous as it is accurate and precise. determines small scale aggregation size, causes little or no damage to the environment or fish, allows observation of fish behavior, and is easy to implement at a very low cost. However, in many environments it may not be possible to use quadrats, as calm, clear water and a vantage point from which an observer can unobtrusively count fish are required. It may be possible to use this technique to standardize other less efficient gear that can be used in a wider variety of environments. Our concurrent sampling using traditional and non-traditional (visual) methods suggests that past studies have underestimated the densities of $L$. xanthurus and that correction factors are required before relative density estimates can be used in ecosystem modeling, carrying capacity estimates or vital statistics of juvenile fish species in the salt marsh habitat.

Acknowledgements. We thank $M$. Smith and J. Bichy for helpful comments on this manuscript. Funding was provided by the Environmental Monitoring and Assessment Program-Estuaries (EMAP-E) grant to UNCW and the North Carolina National Estuarine Research Reserve

\section{LITERATURE CITED}

Begon M, Mortimer M (1982) Population ecology: a unified study of animals and plants. Blackwell Scientific Publications, Oxford

Boesch DF, Turner RE (1984) Dependence of fishery species on salt marsh: the role of food and refuge. Estuaries 7: $460-468$

Currın BM, Reed JP, Miller JM (1984) Growth, production, food consumption, and mortality of juvenile spot and croaker: a comparison of tidal and nontidal nursery areas. Estuaries 7:451-459

Elliott JM (1971) Statistical analysis of benthic invertebrates Freshwat Biol Ass Sci Pub1 25:1-142

Gunderson DR (1993) Surveys of fisheries resources. Wiley \& Sons, New York

Kjelson MA, Johnson GN (1978) Catch efficiencies of a 6.1 meter otter trawl for estuarine fish populations. Trans Am Fish Soc 107:246-254

Krebs CJ (1989) Ecological methodology. Harper \& Row, New York

Miller JM. Dunn ML (1980) Feeding strategies and patterns of movement in juvenile estuarine fishes. In: Kennedy VS (ed) Estuarine perspectives. Academic Press, New York, p 437-448

Miltner RJ, Ross SW, Posey MH (1995) Influence of food and predation on the depth distribution of juvenile spot (Leiostomus xanthurus) in tidal nurseries. Can J Fish Aquat Sci 52:971-982

Peterson GW, Turner RE (1994) The value of salt marsh edge vs interior as a habitat for fish and decapod crustaceans in a Louisiana tidal marsh. Estuaries 17:235-262

Pletrafesa LJ, Janowitz CS, Miller JM, Noble EB, Ross SW Epperly SP (1986) Abiotic factors influencing the spatial and temporal varability of juvenile fish in Pamlico Sound. North Carolina. In: Wolfe DA (ed) Estuarine variability Academic Press, New York, p 341-353

Putman RJ (1994) Community ecology. Chapman \& Hall, London

Ricker WE (1975) Computation and interpretation of biological statistics of fish populations. Bull Fish Res Bd Can 191:1-382

Ross SW, Epperly SP (1985) Utilization of shallow estuarine nursery areas by fishes in Pamlico Sound and adjacent tributaries, North Carolina. In: Yánez-Arancibia (ed) Fish community ecology in estuaries and coastal lagoons: 
towards ecosystem integration. DR(R) Unam Press, Mexico, p 207-232

Rulifson RA (1991) Finfish utilization of man-initiated and adjacent natural creeks of South Creek Estuary, North Carolina, using multiple gear types. Estuaries 14:447-464

Sokal RR, Rohlf FJ (1981) Biometry. Freeman, San Francisco

Talbot CW, Able KW (1984) Composition and distribution of larval fishes in New Jersey high marshes. Estuaries 7: $434-443$

Varnell LM, Havens KJ, Hershner C (1995) Daily variability in abundance and population characteristics of tidal saltmarsh fauna. Estuaries 18:326-334

Vose FE, Bell SS (1994) Resident fishes and macrobenthos in mangrove-rimmed habitats: evaluation of habitat restoration by hydrologic modification. Estuaries 17:585-596

Warlen SM, Burke JS (1990) Immigration of larvae of fall/win-

This note was presented by C. Levings (Senior Editorial Advisor), West Vancouver, $B C$, Canada ter spawning marine fishes into a North Carolina estuary Estuaries 13:453-461

Weinstein MP (1979) Shallow marsh habitats as primary nurseries for fishes and shellfish, Cape Fear River, North Carolina. Fish Bull 77:339-357

W'einstein MP (1983) Population dynamics of an estuarinedependent fish, the spot (Leiostomus xanthurus) along a tidal creek-seagrass meadow coenocline. Can J Fish Aquat Sci 40:1633-1638

Weinstein MP, O'Neil SP (1986) Exchange of marked juvenile spots between adjacent tidal creeks in the York River Estuary, Virginia. Trans Am Fish Soc 115:93-97

Weinstein MP, Scott L, O'Neil, SP, Siegfried RC II, Szedlmayer ST (1984) Population dynamics of spot, Leiostomus xanthurus, in polyhaline tidal creeks of the York River estuary, Virginia. Estuaries 7:444-450

Manuscript first received: June 5, 1996

Revised version accepted: December 27, 1996 